\title{
Modeling lakes and reservoirs in the climate system
}

\author{
M. D. MacKay,,$^{a,}{ }^{*}$ P. J. Neale, ${ }^{b}$ C. D. Arp, ${ }^{c}$ L. N. De Senerpont Domis, ${ }^{d}$ X. Fang, ${ }^{e}$ G. Gal, ${ }^{f}$

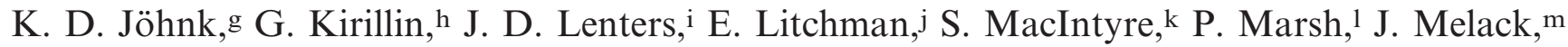 \\ W. M. Mooij, ${ }^{\text {A F. Peeters, }}{ }^{\text {N A. Quesada, }}{ }^{\circ}$ S. G. Schladow,p M. Schmid, ${ }^{\text {q C. Spence, }}{ }^{1}$
} and S. L. Stokes ${ }^{r}$

a Environment Canada, Climate Research Division, Toronto, Ontario, Canada

b Smithsonian Environmental Research Center, Edgewater, Maryland

c U.S. Geological Survey, Anchorage, Alaska

d Department of Aquatic Food Webs, Centre for Limnology, Nieuwersluis, the Netherlands

e Department Civil Engineering, Auburn University, Auburn, Alabama

f Kinneret Limnological Laboratory, Israel Oceanographic and Limnological Research, Migdal, Israel

g Leibniz-Institute of Freshwater Ecology and Inland Fisheries, Department of Limnology of Stratified Lakes, Stechlin-Neuglobsow, Germany

h Leibniz-Institute of Freshwater Ecology and Inland Fisheries, Department of Ecohydrology, Berlin, Germany

i School of Natural Resources, University of Nebraska, Lincoln, Nebraska

j W. K. Kellogg Biological Station, Michigan State University, Hickory Corners, Michigan

k Department of Ecology, Evolution and Marine Biology, University of California, Santa Barbara, California

1 Environment Canada, National Hydrology Research Centre, Saskatoon, Saskatchewan, Canada

$\mathrm{m}$ Bren School of Environmental Science and Management, University of California, Santa Barbara, California

n Department of Biology, Limnological Institute, University of Konstanz, Mainaustrasse, Konstanz, Germany

o Department Biología, Universidad Autónoma de Madrid, Madrid, Spain

p Tahoe Environmental Research Center, University of California, Davis, California

q Eawag: Swiss Federal Institute of Aquatic Science and Technology, Surface Waters_-Research and Management, Kastanienbaum, Switzerland

r Department of Biological Sciences, Clemson University, 132 Long Hall, Clemson, South Carolina

\begin{abstract}
Modeling studies examining the effect of lakes on regional and global climate, as well as studies on the influence of climate variability and change on aquatic ecosystems, are surveyed. Fully coupled atmosphere-land surface-lake climate models that could be used for both of these types of study simultaneously do not presently exist, though there are many applications that would benefit from such models. It is argued here that current understanding of physical and biogeochemical processes in freshwater systems is sufficient to begin to construct such models, and a path forward is proposed. The largest impediment to fully representing lakes in the climate system lies in the handling of lakes that are too small to be explicitly resolved by the climate model, and that make up the majority of the lake-covered area at the resolutions currently used by global and regional climate models. Ongoing development within the hydrological sciences community and continual improvements in model resolution should help ameliorate this issue.
\end{abstract}

It has been long understood that lakes and reservoirs can influence local and regional climate, as open water has significantly different radiative and thermal properties compared with soil or vegetated surfaces. It is not surprising then, that various attempts have been made over the years to include the effects of terrestrial surface water in global and regional climate modeling studies, though the effects considered are usually limited to the flux exchange of moisture, heat, and momentum with the overlying atmosphere. On the other hand, the effect of climate variability and change on thermal structure, water quality, and aquatic ecosystems - also long known to be important-is generally only evaluated in the context of individual lakes or reservoirs. Even though very elaborate models exist for examining these issues, they are generally

\footnotetext{
*Corresponding author: murray.mackay@ec.gc.ca
}

not run fully coupled with global or regional climate models, presumably because of the computational expense or the complexity of such an exercise (or both). Yet to understand the role of lakes and reservoirs in the climate system, fully coupled models must be developed in which key lacustrine processes relevant on climate timescales are integrated within the climate model. This is especially clear given the recent (and growing) awareness of the importance of lakes and reservoirs in the global carbon balance (St. Louis et al. 2000; Tranvik et al. 2009; Williamson et al. 2009). Nutrient loading, biogeochemical cycling, food webs, and ecosystems will all need to be represented, in addition to the thermal structure, mixing regimes, and ice cover that are usually considered in climate modeling studies (i.e., if lakes and reservoirs are considered at all). Modeling techniques exist for all of these, yet it would appear that a fully coupled atmosphere-land surface-lake model that would meet the needs of both the terrestrial 


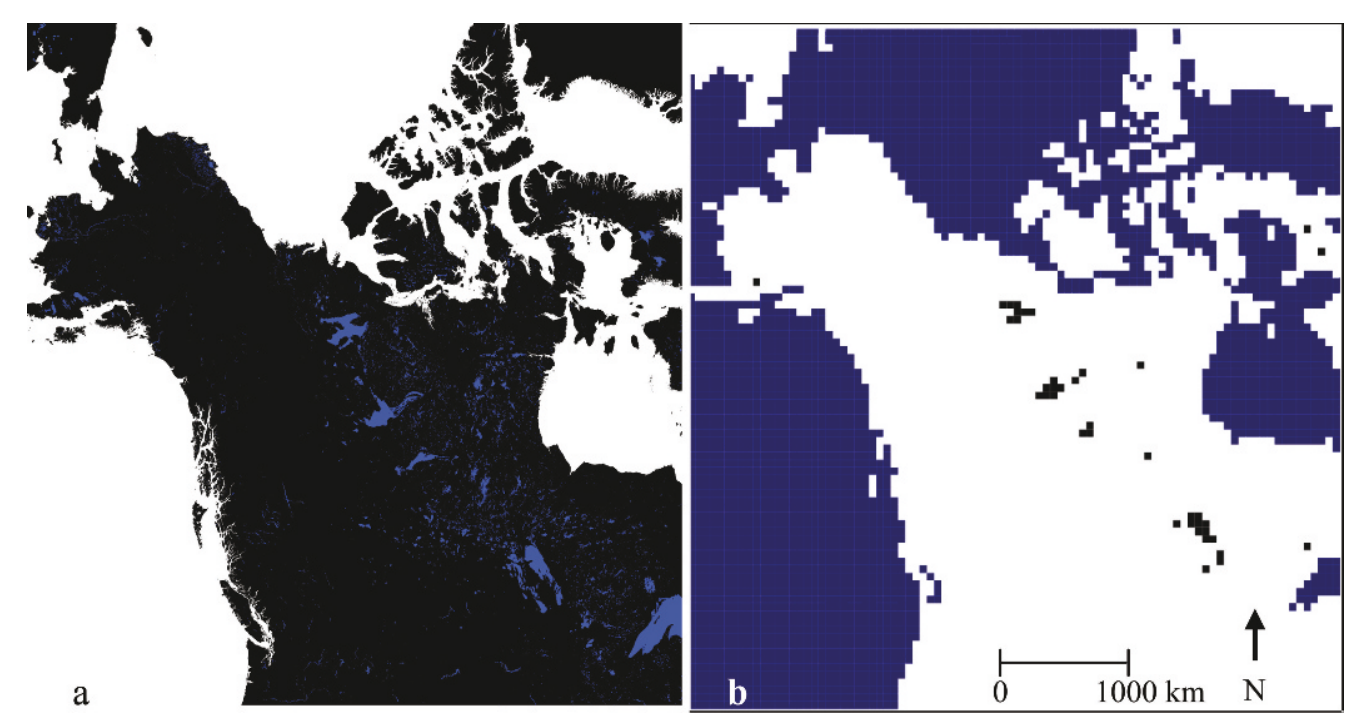

Fig. 1. Distribution of North American lakes: (a) on the basis of satellite remote sensing; (b) as resolved by a typical simulation of the Canadian Regional Climate Model.

climatologist as well as the aquatic ecologist in the context of climate variability and change is lacking.

The following regional climate modeling example serves to illustrate the issue. Consider the boreal forest region of central and western North America, a region in which lakes cover perhaps as much as $10 \%$ of the forested area (Fig. 1a). We are interested in the role that these lakes play in the boreal climate system. It has been shown that the carbon balance of the boreal forest is sensitive to the length and timing of the growing season, which is largely determined by climate conditions - especially air temperature (Black et al. 2000; Arain et al. 2002; Piao et al. 2007). The presence of lakes within the forest will certainly have an influence on the local climate, and thus indirectly on the terrestrial carbon balance. In addition, as pointed out by Tranvik et al. (2009), the emission of carbon from inland waters is comparable with terrestrial net ecosystem production and we must also consider the direct role of lakes in the atmospheric carbon cycle. At the same time we are interested in the effect of climate variability and change, as well as the role of terrestrial nutrient loading (e.g., dissolved organic carbon [DOC], P) and other effects (e.g., wind sheltering) on lake thermal structure and functioning. A coupled atmosphere-land surface-lake model will thus be required.

It is clear that the vast majority of these lakes would be unresolved in typical current-day climate models. For example, Fig. 1b illustrates a domain frequently used in experiments with the Canadian Regional Climate Model (MacKay et al. 2003, 2006; Guo et al. 2007). The horizontal resolution of this grid is approximately $50 \mathrm{~km} \times 50 \mathrm{~km}$, and it can be seen that at this resolution only a handful of grid cells are actually resolved as open water: the vast majority of the lakes indicated in Fig. 1a, which is based on $1-\mathrm{km}^{2}$ resolution satellite data, are simply unresolved. It would be unreasonable, and certainly impractical, to attempt fully three-dimensional (3-D) simulations of so many individual lakes unresolved by the climate model. It should be pointed out that 3-D lake models could be (and have been) coupled with climate models for the occasional large lake found within a domain (Song et al. 2004 for Lake Victoria). However, as discussed below, Downing et al. (2006) determined that $2 / 3$ of the terrestrial surface that is covered by water is made up of small lakes and reservoirs, subgridscale in current-generation climate models. When land surface or hydrological models encounter complex heterogeneous terrain within a grid cell, they frequently model the land surface mosaic by partitioning individual grid cells into "tiles" of similar physical characteristics (Koster and Suarez 1992). In our case we will need to represent dozens (possibly hundreds) of actual lakes in any one grid cell by a small number of effective lake tiles, representing the same total fractional area (so that lakeatmosphere fluxes are handled properly). This is the approach taken by Ljungemyr et al. (1996), who parameterized subgridscale lakes using four tiles on the basis of area and depth. In general the choice of lake tile classification will depend on the functionality of interest (not necessarily area and depth), and the actual number of lake tiles will be limited only by the computational resources available. In any case, it is most appropriate to use one-dimensional (1-D) lake models for each tile. The key question addressed in this study is how to represent such tiles. What key processes have relevance to the climate system that at the same time can be reasonably accommodated within a numerical climate model? In this paper, relevant literature describing existing attempts to include lakes in climate modeling studies, as well as studies that have used models to examine the effect of climate on lake systems, are reviewed, and a path toward a fully coupled atmosphere-land surface-lake climate model is proposed.

Results

Global and regional climate modeling studies - In an early study, Pitman (1991) characterized lakes in a global climate 
model (GCM) essentially as regions of saturated soil, with a fixed roughness length and albedo representative of open water. Evaporation was deemed to occur at the potential rate, and the lake surface temperature (LST) was set to the top soil layer temperature. While neglecting the actual thermodynamic response of lakes, this approach does capture some effects of seasonally wet surfaces evaporating in an unstressed environment: latent heat flux is enhanced at the expense of sensible heat flux.

Even relatively shallow lakes, however, are characterized by significant thermal inertia that drives the surface energy balance away from that of the nearby land surface. Ljungemyr et al. (1996) accounted for this in a forecast modeling study by considering lakes as well-mixed (i.e., isothermal) slabs of fixed depth. When the lake scheme was driven with meteorological observations (i.e., uncoupled to the atmosphere), the model performed reasonably well compared with observed limnological data and simulations from a more sophisticated lake model. Although obviously not simulating the stratified period very well for deeper lakes - lake temperatures were several degrees too cold in summer - the timing of ice on and ice off was improved. In simulations fully coupled with a numerical weather prediction model for a 2-week period in May 1994, the main effect of the lake scheme on the atmosphere was a cooling of near-surface air temperature of up to several degrees in the vicinity of lake regions. This was attributed to simulated ice cover during this period compared with the control simulation without the lake scheme (which assumed lakes were ice free) and highlights the important role of the ice-cover season on atmospheric temperature.

In a similar fashion, Goyette et al. (2000) modeled the Laurentian Great Lakes with a mixed layer of fixed (but spatially varying) depth and uniform temperature, but they represented seasonal variation in the epilimnion by including an ad hoc flux adjustment constraining the simulated surface climate to reproduce observed climatology. In a 5-yr simulation of the Canadian Regional Climate Model coupled with this lake scheme, reasonable monthly mean LST and ice cover were simulated, but the approach is somewhat awkward in that the flux adjustments must be computed off-line for each lake and rely on observed climatology. Although the authors did not systematically analyze the effect of the Great Lakes on the regional climate in the simulation, they did note enhanced wintertime (December-February) precipitation over areas on the leeward side of each of the lakes.

To properly represent diurnal or even seasonal variability in the surface mixed layer, thermal stratification models must be used. These generally fall into two broad categories - eddy diffusion (or differential)-type models and bulk mixed-layer (integral) models (Henderson-Sellers and Davies 1989). Of the two types, eddy diffusion models have thus far been favored in studies examining the effect of lakes on climate. Hostetler and Bartlein (1990) developed a 1-D eddy diffusion model to examine seasonal variations in lake temperature and evaporation. This basic model has been used in numerous applications coupled (or linked) with regional climate models (Bates et al. 1995; Hostetler and Giorgi 1995; Small et al. 1999).
Hostetler et al. (1994) performed 90-d simulations with the regional climate model RegCM coupled with this lake scheme for paleolakes Bonneville and Lahontan, both for $18,000 \mathrm{yr}$ ago and present conditions. They found that the lakes interacted differently with the atmosphere because of different physiographic settings, Bonneville indicating larger precipitation recycling than Lahontan. Thus lakegenerated precipitation was more important to the hydrologic budget of Bonneville, which contributed more to its own self-maintenance than Lahontan, the latter being more controlled by external factors. This lake-atmosphere feedback process illustrates the potential importance of fully coupled simulations.

Bonan (1995) examined the effect of subgridscale inland water-i.e., lakes, swamps, and marshes-in a GCM. Lakes were again modeled as in Hostetler and Bartlein (1990), whereas swamps and marshes were treated as saturated soil. He found that in regions with large inland water fractions, temperatures were $2-3^{\circ} \mathrm{C}$ cooler, latent heat flux was enhanced (10-45 $\left.\mathrm{W} \mathrm{m}^{-2}\right)$, and sensible heat flux was reduced $\left(5-30 \mathrm{~W} \mathrm{~m}^{-2}\right)$ in July in a 5-yr simulation when compared with a control simulation without representation of inland water. Unfortunately there is no way to determine the relative importance of wetlands vs. lakes in Bonan's study.

Using essentially the same lake model as Bonan (1995) and a simple prognostic scheme for wetlands, Krinner (2003) also examined the effect of lakes and wetlands on climate in a GCM, but he analyzed their influence separately. He found that lakes and wetlands can have opposing effects: the cooling, drying effect of lakes on the atmosphere being offset by wetlands when both occurred in the same region, especially in North America. Even though the GCM used in this study used a somewhat simplistic land surface scheme and simulated significant bias in temperature and precipitation, it does highlight the importance of treating wetlands and lakes separately when evaluating the influence of surface water on climate.

In all of the above studies the eddy diffusivity, following Henderson-Sellers (1985), is highly parameterized in a scheme that is formulated under assumptions of unstratified Ekman flow (Smith 1979). The appropriateness of the scheme and how representative it is for lakes in general does not appear to have been systematically evaluated in the literature.

An alternative eddy diffusion formulation makes use of the two-equation $k-\varepsilon$ model of turbulence with eddy diffusivity generally parameterized via the Prandtl-Kolmogorov relation, or a modified version taking account of mixing in the hypolimnion (Stigebrandt 1987; Omstedt and Axell 1998). The PROBE (program for boundary layers in the environment) lake model, originally based on Svensson (1978), takes this approach. It has been used in numerous studies of Nordic lakes (Sahlberg 1988; Elo 2005, 2007), Baltic Sea studies (Omstedt and Sahlberg 1983; Omstedt and Nyberg 1996; Omstedt and Axell 1998), and has been coupled with (or driven by) regional climate models for both current and future climate scenarios (Rummukainen et al. 2001; Blenckner et al. 2002; Malmaeus et al. 2006). Generally these studies have focused attention on the 
performance of the lake model itself, or on the effects of climate variability and climate change on lake function or thermal structure, rather than on interaction with the regional climate system.

On the other hand, bulk mixed-layer models (Niiler and Kraus 1977) do not appear to have been used in coupled lake-atmosphere modeling studies to any great extent, though they have been successfully used in studies of individual lakes and reservoirs (Imberger 1985; Spigel et al. 1986).

Modeling aquatic greenhouse gas emissions-Three greenhouse gases (GHGs) are potentially emitted from lakes and reservoirs: carbon dioxide, methane, and nitrous oxide. Variability in GHG fluxes from lakes and reservoirs has been attributed to their age, residence time, nature and type of vegetation and soils inundated, quantity of biomass inundated, morphometry, operational conditions, nutrient status, and carbon sources, as well as climatic influences (St. Louis et al. 2000; Bastviken et al. 2004; Thérien and Morrison 2005). Methane fluxes appear to have the greatest significance relative to global GHG budgets (Bastviken et al. 2004; Chen and Prinn 2006). A detailed review of experimental and observational studies of GHG emissions from lakes and reservoirs can be found in the article by Tranvik et al. (2009).

There are three major routes of methane flux from lakes: (1) diffusive emission from the water surface to the atmosphere, (2) bubbles released from the sediments, and (3) plant-mediated emission in shallow areas (Bastviken et al. 2004). In the case of hypolimnetic withdrawal from a reservoir, methane emission from the turbines and downstream river can be another major source (Guérin et al. 2006; Kemenes et al. 2007). All of these fluxes are spatially and temporally variable, are influenced by mixing events (Engle and Melack 2000), lake level fluctuations (Ostrovsky 2003) and currents (Joyce and Jewell 2003), and are episodic (Ramos et al. 2006). Many studies calculating regional gas flux from lake systems are based on conservative values of the gas transfer coefficient and likely underestimate the role of aquatic ecosystems in gas flux (Richey et al. 2002). Approaches to quantify the gas transfer coefficient that take into account processes producing turbulence at the air-water interface are described in Banerjee and MacIntyre (2004) and can be computed in hydrodynamic models.

A process-based model for predicting methane emissions from a lake or reservoir should include the sources of organic carbon to the lake and its transformation to methane, as well as the pathways of methane emission as a function of external forcing and lake characteristics. Process-based models have been developed for the fate of organic carbon in lakes (Hanson et al. 2004), the release of methane bubbles from lake sediments (Makhov and Bazhin 1999), the dissolution of methane during the rise of the bubbles through the water column (McGinnis et al. 2006), and gas exchange between the lake surface and the atmosphere (Guérin et al. 2007). A 1-D reaction-transport model has been applied to the Lake Baikal methane balance (Schmid et al. 2007). Whole lake and reservoir
GHG flux modeling approaches have included the development of regression models (Bastviken et al. 2004) and methane budgets (Bastviken et al. 2008), as well as dynamical numeric approaches (Abril et al. 2005; Thérien and Morrison 2005). However, a model that integrates all of the relevant processes and could be applicable to a large range of reservoirs and lakes remains to be developed.

Effects of climate variability and change on lakes and reservoirs - In aquatic systems physical and biological processes may be more tightly coupled than in terrestrial ecosystems because of the close match of the characteristic timescales of physical forcing and the responses of the biota (Steele 1985). This tight coupling makes the adequate interfacing of the physical and biological models especially important. Multiple physical processes will be affected by climate variability and change. For example the onset, duration, and strength of stratification are already changing in response to increasing air temperatures (Lehman 2002; O'Reilly et al. 2003) and affecting aquatic ecosystem functioning. Other climate elements such as precipitation, cloud cover, wind speed, ultraviolet (UV) and photosynthetically active radiation (PAR), and stream flow can also influence aspects of aquatic systems and numerous modeling studies have addressed these. The following sections briefly review some of these studies. Lake and reservoir response to climate change is covered in greater depth in the article by Adrian et al. (2009).

Modeling lake thermal structure and mixing regimesClimate affects aquatic ecosystems mainly through its influence on physical conditions in lakes and reservoirs. Changes in water temperature, mixing regime, and the timing and duration of stratification and ice cover have implications for primary production, predation and growth rates of zooplankton and fish, nutrient supply, and deepwater anoxia. Because interactions within the food web and between the food web and the environment are nonlinear, even small changes in habitat conditions might lead to significant consequences of climate change for lake functioning. Hence, a key factor in linking climate conditions and aquatic ecosystems is an understanding of the effects of climate change on the physical conditions in lakes and of the response of ecosystem interactions to changes in thermal stratification and mixing regime.

The effect of climate on seasonal temperature stratification, mixing conditions, and ice-cover duration in lakes has been studied by several investigators using 1-D modeling approaches (Blenckner et al. 2002; Danis et al. 2004; Peeters et al. 2007a). One-dimensional models have been used because they are sufficiently fast to allow long-term simulations over decades and even centuries, and have performed well in simulating the seasonal and interannual variations of the temperature distribution in lakes (Peeters et al. 2002). In fact, in terms of a global or regional coupled atmosphere-land surface-lake modeling system that is of interest here, there will be no choice but to use 1-D lake modules. Downing et al. (2006) estimate that of the $>3 \%$ continental land surface that is water covered, nearly $2 / 3$ is made up of lakes, ponds, and impoundments that are 
smaller than $100 \mathrm{~km}^{2}$ (see their table 2). Most global and even regional climate models cannot currently run at such high resolution, and these lakes will be subgridscale, i.e., not explicitly resolved but parameterized.

Seasonal mixing dynamics in freshwater bodies is generally one of four types-polymictic, dimictic, and warm or cold monomictic. Modeling studies have focused more on temperate water bodies but many of the results can be extrapolated to tropical and polar systems. Several studies show that a shift to higher air temperature leads to a similar shift in epilimnetic water temperatures in dimictic lakes (Hondzo and Stefan 1993). In these lakes both the strength and duration of stratification are projected to increase significantly (Huttula et al. 1992; Elo et al. 1998; Peeters et al. 2007a). Climate warming can lead to transition from a dimictic to a warm monomictic regime if the minimum winter temperatures increase above $4^{\circ} \mathrm{C}$. Higher temperatures in combination with decreased wind speeds could trigger transition of shallow polymictic lakes to the dimictic regime. Transparency plays an important role here (in contrast to the dimictic-monomictic transition where it does not): a decrease in transparency accelerates transition to the dimictic regime. Hence, any long-term prediction of the mixing regime in shallow lakes remains uncertain without a future scenario for water quality.

In deeper, monomictic lakes, overturn typically occurs when air temperature reaches its annual minimum. Thus, deep-water temperatures in the hypolimnion of monomictic lakes will increase when annual minimum air temperatures become higher. Monomictic lakes will therefore experience a larger increase in deep-water temperatures and a smaller increase in stratification than lakes with regular ice cover (Peeters et al. 2002). Depending on the rate of air temperature rise these lakes can become temporarily meromictic (Matzinger et al. 2007).

Light transmission-Thermocline and euphotic zone depths, UV penetration depths, vertical migration, and the extent of cold-water refugia are all influenced by lake transparency, and are important factors in governing aquatic ecosystems. For small boreal oligotrophic lakes it is generally understood that colored dissolved organic matter $(\mathrm{CDOM})$ is the primary determinant of transparency, and variability in loading of DOC is likely to play an important role in key aspects of the physical lake system (Fee et al. 1996; Schindler et al. 1997). Schindler et al. (1996) have proposed that prolonged warm and dry periods would result in lower DOC concentrations. Fee et al. (1996) found that variations in the transmissivity of light through the top meter of water ranging from $10 \%$ to $80 \%$ were associated with systematic variations in epilimnion depth of up to $2 \mathrm{~m}$ in an observational study. They have proposed that under a $2 \times \mathrm{CO}_{2}$ (atmospheric) climate change regime epilimnia would deepen by 1-2 m. Arctic lakes found in tundra regions similarly have their light attenuation dominated by CDOM.

These studies are suggestive of the potentially important role of DOC variability in the dynamics of small boreal (and arctic) lakes; however, none has systematically investigated this variability in the context of a numerical model that includes both the dynamics of epilimnion deepening and retreat as well as the effect of DOC concentration on transparency. It is clear that prognostic simulation of boreal and arctic lakes in the context of climate change will require dynamic simulation of DOC input generated by terrestrial runoff as well as consideration of in situ processes (e.g., photobleaching). Land surface models that include carbon cycling, surface runoff, and even stream-flow routing already exist, of course, though to our knowledge none has been fully coupled with a dynamic lake model.

Both dissolved and particulate matter influence light transmission. In eutrophic lakes and lakes with low concentrations of CDOM, phytoplankton and suspended sediment will determine the light transmission profile. In an altered climate in which phytoplankton productivity of oligotrophic boreal or arctic lakes increases with concomitant increases in algal biomass, or if enhanced stream inflows induce more scouring, modeling efforts will need to include the effects of increased particulates.

Climate change can influence both the total amount and spectral distribution of light (Pienitz and Vincent 2000), so detailed modeling of the light environment may be necessary to predict climatic effects on wavelength-sensitive processes. This may require resolving UVB, UVA, and different colors of visible light (Kirk 1994). However, simple, single-parameter models can also be useful to highlight the effect of changing light absorption on thermal stratification (Persson and Jones 2008). For example, a time-series model of Secchi disk visibility in Lake Tahoe suggested that atmospheric particle inputs were playing at least as important a role as algal growth in controlling the long-term shoaling trend in Secchi depth (Jassby et al. 2003). Most of the variation in the UV transparency in lakes can be modeled as a simple relationship with DOC (reviewed by Hargreaves 2003). Similarly, many current ecosystem models represent incident irradiance and underwater irradiance as just PAR or total shortwave radiation, yet models can be adapted to incorporate the spectral effects of climate change. Spectral information is used, for example, in the calculation of the pigment absorbance weighted, photosynthetically utilizable radiation (Lohrenz et al. 2004) and the strong wavelength dependency of UV effects like inhibition of photosynthesis, zooplankton mortality, and photobleaching (Neale and Kieber 2000). A frequently used approach to incorporating some spectral resolution is to construct a semianalytical bio-optical model in which the optical signatures of algae, CDOM, and suspended particulates (absorption and scattering) are related to apparent optical properties such as spectral attenuation (Swift et al. 2006).

Shallow lakes - Shallow lakes typically have no persistent thermal stratification nor stratification regime, a lower heat storage capacity, a larger surface-to-volume ratio, and are likely to show a strong temperature linkage between air and water (Gerten and Adrian 2001; Straile et al. 2003). Understanding the interaction between shallow lakes and the climate system is of particular interest for regions where 
such lakes occur in very high densities (e.g., in permafrost, periglacial, and riverine landscapes).

Since the pioneering work of Birge et al. (1927) it has been understood that heat storage by lake sediments can significantly affect the seasonal heat budget of shallow lakes. The thermal effect of sediments is especially pronounced on seasonal timescales in temperate and subpolar lakes (Pivovarov 1974), though it can also introduce a lag in the thermal response of lakes at diurnal and synoptic scales (Fang and Stefan 1996). Numerous modeling studies on shallow lake response to regional climate change are based on 1-D lake temperature models, but only a few include the thermal influence of lake sediments (Mironov et al. 1991; Fang and Stefan 1997a).

Apart from a strictly abiotic thermal response of shallow lakes to climate change, shallow lakes will also most likely show a broader ecosystem response. Shallow lakes can typically be characterized by one of two contrasting equilibrium states: a clear state with submerged macrophytes or a turbid state dominated by phytoplankton (Scheffer et al. 1993; Carpenter 2003). The phytoplanktondominated turbid state is generally considered as undesirable, because natural communities characterized by macrophytes and a rich fish fauna disappear and biodiversity decreases. Several factors determine which state prevails in any given case, though a general constraint is set by the external nutrient loading. At a very high loading, only the turbid state is stable, whereas the opposite is true for very low loadings. In the intermediate range, both states may exist and transitions between the two states are possible. Because both states possess a number of self-stabilizing buffering mechanisms, the system shows hysteresis: the critical loading level at which a shift occurs is dependent on the past history of the system. The shift from turbid to clear occurs at a much lower loading level than vice versa. By simulating a range of climate warming and nutrient loading scenarios, Mooij et al. (2007) showed that climate change will likely lead to decreased critical nutrient loadings. Combined with an expected increase in the external nutrient loading, this will increase the probability of a shift from a clear to a turbid state. The turbid state itself is expected to be more severe because of a higher summer chlorophyll $a$ concentration, a stronger dominance of cyanobacteria during summer, and a reduced zooplankton abundance due to climate change.

Some of the largest lake densities at high northern latitudes occur in regions of permafrost thermokarsting (Smith et al. 2007) with lake surface area fractions exceeding 20\% in many areas (Hinkel et al. 2005; Emmerton et al. 2007). These thermokarst (or thaw) lakes occur at the highest densities where ice-rich permafrost degradation creates surface storage in otherwise impermeable soils with very limited groundwater flow (Woo 2000). Small arctic lakes located in areas of ice-rich permafrost are very sensitive to changes in climate (Mackay 1992; Brewer et al. 1993), as lake area may change because of several factors including: a change in the lake water balance and hence lake level (Bowling et al. 2003; Plug et al. 2008); increased groundwater outflow as permafrost degrades; catastrophic drainage (Mackay 1988, 1992); or erosion and melting of the shoreline (Hinkel et al. 2007). Increases and decreases in lake area over both decadal and annual timescales have been reported for Siberia, Canada, and Alaska as a consequence of global climate change (Yoshikawa and Hinzman 2003; Smith et al. 2005) and interannual variability (Plug et al. 2008). Such changes in surface area pose an additional modeling challenge under a changing climate, and are not generally included in existing models.

These lakes may also have high algal biomass due to the introduction of nutrients from melting permafrost. The introduction of organic matter, particularly at lake formation, leads to methane production and release by ebullition (Walter et al. 2007). Coupled lake-climate models that dynamically account for changes in lake surface area due to shifting water balance and potential episodic basin drainage or expansion, as well as dynamics of methane release, will be particularly important in arctic permafrost environments. Models of the hydrology of arctic thaw ponds (Marsh and Lesack 1996) provide a starting point. Similar coupled modeling may be critical in other regions of the world where lakes are very abundant and there are strong interactions between lake area extent and climate such as large river floodplains and coastal deltas. In addition, dynamically accounting for the total area of reservoirs and impoundments - already substantial compared with natural lakes and growing at a rate of $1-2 \%$ per year (Downing et al. 2006) - will be important for any longrange prediction of the total freshwater carbon budget.

Ice cover-Lake ice characteristics such as ice-cover duration, ice-on and ice-off dates, and ice thickness have a profound effect on lake ecology due to their influence on temperature, water column stability, nutrient concentrations, gas exchange, and light availability. Ice thickness and structure represent important factors governing radiation distribution and availability through the ice-covered season (Fritsen and Priscu 1999; Belzile et al. 2001). It has also been suggested that (at least for high-latitude lakes) one of the most important primary production peaks takes place under ice (Tanabe et al. 2008). Assuming that the bloom is triggered by the amount of light available, a change in ice thickness may modify the bloom timing, thus potentially decoupling primary production from consumers (Winder and Schindler 2004).

Ice-cover duration effects are particularly pronounced at high latitudes where the ice-free period is relatively short. Under ice-covered conditions the water column is typically stratified, producing nutrient dynamics with strong vertical gradients (Vincent 1988) with relatively warm, nutrient-rich lake bottoms. Any variation in the length of the ice-cover duration will represent a change in nutrient availability: less time for anaerobic mineralization processes during winter could lead to a reduction in nutrients. Other aspects such as gas accumulation will also be modified because of changes in the duration of the ice-cover period. In polar lakes, where the ice-free period is not longer than a few weeks (Quayle et al. 2002), a slight variation in the ice-free period could be highly relevant for lake functioning. In a longer ice-free period scenario a larger exposure to UVB radiation 
would be expected. That UVB exposure could be especially damaging considering the cold conditions under which metabolic repairing systems are slower (Vincent and Quesada 1994). In small arctic lakes DOC and nutrients introduced at snowmelt are far in excess to that produced internally and are critical for seasonal productivity. This meltwater flows in under the ice: modeling whether it is dispersed throughout the lake or quickly exits the lake will be important for predicting productivity and for understanding interannual variability.

Nutrient loading, water quality, food webs, and ecosystems-Dissolved oxygen (DO) concentration is one of the most important water-quality parameters as it indicates the overall status of eutrophication, the degree of pollution, and the ecological health of a water body, and numerous studies have examined the effect of climate variability and change on this parameter. For example, the effect of potential climate warming on DO concentrations in Lake Erie was studied by Blumberg and Di Toro (1990). Using a hydrodynamic and eutrophication model and climate scenarios from three GCMs, they projected maximum epilimnetic DO change of about $1.0 \mathrm{mg} \mathrm{L}^{-1}$ in July. The projected hypolimnetic DO losses were typically 1$2 \mathrm{mg} \mathrm{L}^{-1}$ and up to $5 \mathrm{mg} \mathrm{L}^{-1}$ on some days. These results are similar to those obtained for large shallow lakes in Minnesota by Stefan and Fang (1994), who used a regional lake DO model to simulate daily DO profiles during the open water season (March to November) under past (1955 to 1979$)$ and $2 \times \mathrm{CO}_{2}$ future climate scenarios. The model included reaeration at the water surface and photosynthesis as oxygen sources, and oxygen consumption by sedimentary oxygen demand, water-column biochemical oxygen demand, and plant respiration. They found decreasing daily mean epilimnetic DO concentrations under a warming climate and large variability in the daily mean hypolimnetic DO concentrations across the open water season and among lake classes. The low bottom DO period $\left(0.1 \mathrm{mg} \mathrm{L}^{-1}\right)$ is projected to increase by as much as $80 \mathrm{~d}$ in southern Minnesota lakes and $60 \mathrm{~d}$ in northern Minnesota lakes. Fang and Stefan (1997b) used a regional DO model that included ice cover for lakes in Minnesota and found that oxygen depletion in winter ice-covered lakes was strongly related to trophic state: shallow oligotrophic lakes had no DO depletion, whereas under identical weather conditions, eutrophic lakes had DO depletion in winter.

Nutrient loading determines ecosystem functioning and food-web structure and is also sensitive to climate perturbations. Internal nutrient loading, $\mathrm{P}$ in particular, depends on DO concentration in and near the sediments, with $\mathrm{P}$ release stimulated by anoxic conditions (Carpenter et al. 1999; Sondergaard et al. 2003). Therefore, to accurately predict changes in internal nutrient loading, dynamic models of the vertical distribution of DO are essential. Internal nutrient loading also depends on water temperature: higher temperatures may enhance ammonification through higher decomposition rates, but at the same time nitrogen may increasingly disappear to the atmosphere because of higher denitrification rates (Coops et al. 2003; Weyhenmeyer et al. 2007). Modeling changes in external nutrient loading will require an adequate representation of precipitation because increases in runoff will bring in more nutrients (Andersen et al. 2006; Rip et al. 2007). Increases in precipitation frequency and intensity would lead to decreases in hydraulic retention time, shifting the relative importance of internal loading processes to external loading processes on nutrient dynamics. Whether incoming nutrients enter the euphotic zone and whether they become persistent metalimnetic intrusions depend on stream temperatures and mixing dynamics as incoming waters enter a basin and before they plunge to the depth of neutral buoyancy. Thus, consequences of stream inflows will vary with changes in lake stratification and surface forcing.

Predicting lake ecosystem response to climate change will also require an adequate resolution of changes in the vertical distribution of nutrients, e.g., due to changes in mixing regimes. Stronger stratification may reduce the amount of nutrients supplied to the epilimnion by suppressing vertical mixing, thereby decreasing primary productivity and (consequently) fish yields (O'Reilly et al. 2003). As noted above, Mooij et al. (2007) showed that climate warming will also lead to lower critical nutrient loadings (nutrient concentrations leading to ecosystem state transitions).

Plankton succession in spring and early summer can be highly sensitive to meteorological forcing (Straile and Adrian 2000; Straile 2002; Straile et al. 2003). Several studies indicate that the onset of phytoplankton net increase in lakes is strongly related to the timing of ice off (Adrian et al. 1999; Weyhenmeyer et al. 1999) and to the mixing conditions in spring (Bleiker and Schanz 1997). In deep monomictic lakes interannual variation in the onset of phytoplankton growth in spring is mainly determined by the interannual variations in the transition from strong to weak mixing and only weakly depends on interannual variations in solar radiation or water temperature (Peeters et al. 2007b). Because higher air temperatures lead to a significant shift in the timing of spring mixing, the onset of phytoplankton growth is predicted to be shifted to earlier times in the year in a warmer climate (Peeters et al. 2007a). Since climate warming affects the timing of primary production, it may also have consequences for herbivore abundance and affect the entire plankton succession.

The development of populations of Daphnia, the keystone herbivore in most freshwater lakes, is closely related to water temperature, but not to mixing conditions or phytoplankton biomass as was demonstrated in statistical (Straile 2000; Straile and Adrian 2000) and modeling (Schalau et al. 2008) studies. For example, results from a one-box algae-Daphnia model (Scheffer et al. 2001) suggest that an increase in water temperature produces a significant shift of the clear-water phase to earlier times in the year.

Because phytoplankton and zooplankton have different cues for spring development, temporal shifts in some of these cues can cause a mismatch in the timing of population increase and, consequently, a disruption in phytoplanktonzooplankton trophic coupling (Winder and Schindler 2004). De Senerpont Domis et al. (2007) modeled the 
effect of the dominant source of Daphnia population growth (emergence from resting eggs vs. overwintering in the water column) on phytoplankton-zooplankton coupling. They found that when a population started from a small population of resting eggs, extreme climate warming $\left(+6^{\circ} \mathrm{C}\right)$ resulted in a decoupling of trophic relationships, and the clear-water phase failed to occur. In other scenarios, even if the model showed a mismatch of algae and zooplankton, the trophic relationships between Daphnia and its algal food source remained intact. Analysis of 36 temperate lakes shows that shallow lakes have a higher potential for climate-induced mismatches, as the probability of active overwintering daphnids decreases with lake depth.

The timing of seasonal phytoplankton and zooplankton peaks also affects higher trophic levels, such as juvenile fish (Benndorf et al. 2001; Wagner et al. 2004; Straile et al. 2007). In a modeling study of fish recruitment in the shallow Dutch Lake Tjeukemeer, an earlier onset in the growth of larval bream of about $20 \mathrm{~d}$ was shown (Mooij et al. 2008). Earlier spawning could result in increased planktivory, which through trophic cascades could lead to increased algal biomass. Earlier spawning, however, could also result in a mismatch between larval feeding and prey abundance (Cushing 1990).

A crucial change in aquatic ecosystems with far-reaching consequences for food-web structure and water quality is the predicted increase in harmful algal (mostly cyanobacterial) blooms under a warming climate (Paerl and Huisman 2008). Many nuisance species of cyanobacteria have higher temperature optima for growth than other phytoplankton and are thus preferentially stimulated by warmer temperatures (Robarts and Zohary 1987; Blenckner et al. 2002). In addition, a more stable lake stratification caused by increasing temperatures also favors cyanobacteria by increasing their competitive advantage because of cell buoyancy (Humphries and Lyne 1988; Ibelings et al. 1991; Jöhnk et al. 2008). Adrian et al. (1995) describe a change in phytoplankton community structure from one dominated by diatoms and cryptophytes to that by cyanobacteria related to mild winters. Conditions during winter may also affect the distribution of species in spring and thus the succession pattern of the whole year (Adrian et al. 1999). Studies on shallow Dutch lakes (Moed and Hoogveld 1982; Reeders et al. 1998) showed that filamentous cyanobacteria, mainly Planktothrix agardhii, were more abundant after ice-free winters than following periods of prolonged ice cover.

Compared with other plankton species, the coccoid Microcystis spp. show a very high $Q_{10}$ value for the growth rate (Reynolds 1997) and thus may catch up with competitors as the water gets warmer. It has also been proposed (Shapiro 1997) that elevated water temperatures promote the benthic recruitment of Microcystis cells or colonies, which may partly explain sudden blooms of Microcystis during spells of warm weather. The possibility of an increased prevalence of toxic species in this genus has raised alarm; however, any increase in cloud cover or wind speed (for example as is occasionally predicted for northwestern Europe) would weaken thermal gradients and offset the competitive advantage derived by cyanobacteria from their buoyancy regulation.

More recently, a shift in diatom community structure has been documented in response to climate change at Lake Tahoe (Winder et al. 2009). Increased stratification and reduced nitrogen-to-phosphorus ratios selected for smallcelled diatoms, particularly within the Cyclotella genus. The increase in small-celled species was sufficient to decrease the average diatom size and thus sinking velocity, strongly influencing energy transfer through the food web and the rate of carbon cycling.

To predict shifts in phytoplankton community composition, there should be an adequate resolution of different functional and taxonomic groups of phytoplankton. Modeling different functional groups of phytoplankton is well developed for oceanic systems, where several functional groups such as diatoms, cyanobacteria ( $\mathrm{N}$-fixers), and picoplankton are parameterized (Moore et al. 2002; Litchman et al. 2006). Although it would seem desirable to distinguish between toxic or harmful species and others, in practice it is difficult to establish functional classes that can accomplish this. Recent models of freshwater phytoplankton included several dominant taxa, representing diatoms, green algae, and cyanobacteria (Elliott et al. 2002, 2005; Mieleitner and Reichert 2008). The identity of the modeled functional groups of phytoplankton may change depending on the type of lake ecosystem being modeled (e.g., oligotrophic, eutrophic, etc.). An alternative approach to including a predetermined number of phytoplankton functional groups is to model a continuum of species with different values of traits and let environmental conditions select for certain types (Follows et al. 2007).

\section{Discussion}

Studies examining the interactions among the atmosphere, land surface, and aquatic systems in a fully interactive way at regional or global scales do not exist because fully coupled models that incorporate all the processes known to be important have not been attempted. This article has surveyed modeling studies that analyze the influence of lakes on global and regional climate systems, as well as those that examine the effects of climate variability and change on lakes, and has attempted to summarize the required elements of the lake component of a fully coupled atmosphere-land surface-lake modeling system.

Because of the central role that the epilimnion plays in both the thermal and trophic structure of most lakes, it is essential that turbulent mixing processes be represented in our lake model. Of the two basic approaches to turbulent mixing in a 1-D context, eddy diffusion models have dominated the literature in terms of lake-climate interaction, with North Americans tending to favor the formulation of Henderson-Sellers (1985), whereas Europeans appear to prefer the $k-\varepsilon$ model of turbulence. Both have been used successfully, though both have inherent weaknesses. One weakness they share is that the concept of eddy diffusion itself breaks down in the presence of weak gradients - certainly a problem in the hypolimnion if 
temperature observations are used to estimate eddy diffusivities (e.g., for nutrient or oxygen transport from sediments). The second approach to turbulent mixing - the bulk mixed layer model-does not appear to have been investigated in the published climate-modeling literature (though Mironov [2006] describes a similar approach). At this point we cannot recommend one approach over another, but can suggest that continued research on this issue would be beneficial.

Ice-cover duration and timing are sensitive to climate variability and change and can have important effects at all trophic levels. In addition, ice-cover duration affects both winter and summer anoxia, which influences both ecosystem functioning and nutrient dynamics (especially in the sediment). All of the lakes in Fig. 1a will experience either partial or complete seasonal ice cover, and an ice model that at least reproduces ice-on and ice-off dates will be an essential component. Springtime ice conditions are especially critical to food-web dynamics, and help characterize the nature of the subsequent stratified period, suggesting that ice-off dates will be particularly important.

The role of benthic processes (both thermal and biogeochemical), especially in shallow lakes, will need to be considered, though there is probably insufficient data over a region such as shown in Fig. 1 to develop definitive algorithms. Even if nutrient and oxygen processes within the sediment were well represented numerically, there would still exist considerable uncertainty regarding the flux exchange, and ensuing transport of these substances within the hypolimnion due to uncertainty in eddy diffusivity. Although turbulence is typically weak within the bulk of the hypolimnion, mixing is enhanced near lake margins in the bottom boundary layer along the slopes (Wüest and Lorke 2003). Energy required for this mixing is introduced by the wind at the lake surface and redistributed over the whole lake depth by seiching and internal waves. This is the major source of energy in the hypolimnion of stratified lakes and needs to be parameterized in 1-D models (Goudsmit et al. 2002; Yeates and Imberger 2004) to simulate eddy diffusion in the hypolimnion.

Light transmission through the water column is paramount in the determination of lake thermal structure and ecosystem state, and in this regard the importance of terrestrial processes has become increasingly clear. For example, in small boreal and arctic lakes transparency is largely governed by DOC and suspended material that is flushed into the lakes through surface runoff events. Thus modeling the terrestrial water balance and carbon cycle will be required to determine the carbon inputs for these lakes. Of course, in situ carbon cycling (e.g., photobleaching) in the lake itself will also need to be represented: changes in the relative proportion of allochthonous vs. autochthonous DOC will strongly affect lake transparency (Adrian et al. 2009). Modeling the lake carbon cycle is at any rate required to estimate lacustrine GHG fluxes, which are of growing interest in the climate change community. In addition, modeling terrestrial runoff is essential for determining nutrient fluxes into lakes, providing a direct link between climate variability (especially precipitation) and ecosystem response. It is clear that a fairly compre- hensive land surface model that includes a complete representation of the hydrological cycle as well as aspects of terrestrial carbon and nutrient cycling will be an important component of a lake modeling system in the context of climate change research. In addition, there may be circumstances where the land surface model will need to represent unresolved atmospheric processes such as wind gustiness and sheltering due to trees and microtopography.

The level of eutrophication will also have an effect on light transmission, and sufficient biogeochemical cycling will need to be included in the lake model for this reason, as well as the obvious influence on water quality and ecosystem health. Numerous freshwater biogeochemical models of varying degrees of complexity already exist, and we have not attempted to evaluate which would be most appropriate in the climate modeling context of interest here. We simply point out that to represent lake transparency dynamically (required for any climate change experiment for example) we will require not only a sophisticated land surface scheme, but also sufficient biogeochemical cycling to determine the trophic state and color of the lake. As a minimum, we suggest this will require three trophic levels - primary producers, secondary producers, and decomposers, as well as the cycling of five chemical constituents - carbon, oxygen, phosphorus, nitrogen, and silica, in their various forms. The physical and chemical requirements of our proposed lake model are presented in a highly schematic form in Fig. 2.

For resolved lakes, the transport of nutrients from the land surface scheme is accomplished through explicit stream channel networks. For example, MacKay et al. (2003) computed a surface water balance for the Mackenzie River basin on the basis of a simulation of the Canadian Regional Climate Model, and used that water balance to drive a river routing scheme that included representations of both Great Slave and Great Bear lakes (Fig. 3). Although the focus of that study was squarely on the hydrology, it would have been straightforward to include transport of nutrients and even heat into these lakes. A more significant problem exists for stream connections among subgridscale lakes not explicitly resolved in the climate model. This confounds the simulation of external sediment, carbon, and nutrient loading and parameterized estimates of subgridscale stream flow into and out of each lake tile will be required. Current parameterization schemes of subgridscale stream flow, termed "tile connectors," are rudimentary. The Canadian Land Surface Scheme (Verseghy et al. 1993), for example, uses a simple additive approach that does not permit any interaction among subgridscale lake or terrestrial tiles. This approach has thus far been unsuccessful in reproducing stream flow in lakedominated landscapes (Spence 2001). Theory and methodology both exist within the hydrology community for parameterizing how stream network distribution influences runoff response (e.g., the geomorphic instantaneous unit hydrograph-Rodriguez-Iturbe and Valdes 1979). These approaches currently require drainage networks that are invariant over space and time. The presence of lakes often results in dynamic networks with intermittent stream flow (Kusumastuti et al. 2007), which violates this assumption. 
a) Energy flows

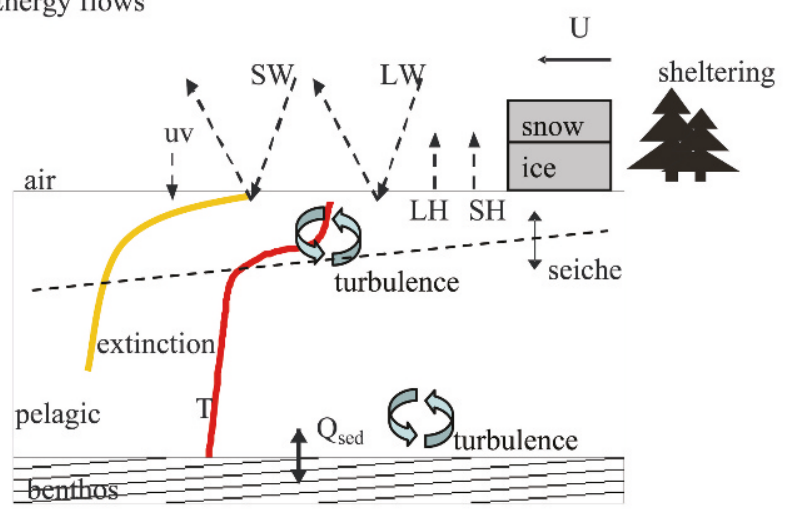

b) Mass flows

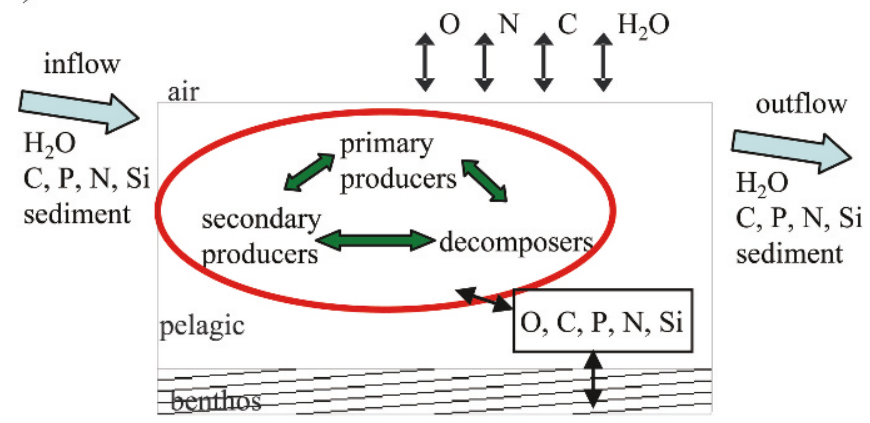

Fig. 2. Schematic process diagram for proposed lake tile: (a) energy flows: LW, long-wave radiation; SW, shortwave radiation; $\mathrm{UV}$, ultraviolet radiation; $\mathrm{LH}$, latent heat flux; $\mathrm{SH}$, sensible heat flux; $Q_{\text {sed }}$, sediment heat flux; $U$, wind speed. Profiles of light extinction and temperature are also indicated. (b) Mass flows: heavy blue arrows indicate terrestrial flux exchange of water and nutrients, heavy green arrows represent biomass exchange among functional groups, black arrows represent flux exchange of chemical constituents of the lake with the atmosphere and benthos.
If nutrient and sediment loading are to be successfully modeled in small lakes, it will be critical to parameterize subgridscale stream and lake connectivity in intermittent systems.

Finally, it should be noted that the uncertainty associated with the modeling of future climatic conditions must be considered in addition to the inherent uncertainty associated with trying to predict trophic interactions and ecosystem response to climate change (Winder and Schindler 2004; Ficke et al. 2007). Few studies to date have attempted to include climate prediction uncertainty in ecosystem modeling studies directly (Preston 2006; Preston and Jones 2008). This will likely require multimodel or multiscenario (or both) ensembles of climate simulations as a starting point: ecosystem studies on the basis of single realizations of a climate model projection will become increasingly less credible as continual advances in computing power along with reductions in computing costs eliminate barriers to more intensive numerical experimentation. This is not a factor in the construction of coupled modeling systems as such, but rather a comment on experimental design.

\section{Acknowledgments}

This synthesis article was assembled as part of the American Geophysical Union Chapman Conference on "Lakes and Reservoirs as Sentinels, Integrators, and Regulators of Climate Change," convened by C. Williamson and J. Saros at the Tahoe Environmental Research Center, 08-10 Sep 2008. It is not only a product of the listed authors who comprised the writing team, but also of a larger working group on "Scaling and modeling the role of lakes and reservoirs in climate change," as well as other conference participants who substantially improved the article through their contributions of ideas, discussion, and detailed comments as the manuscript evolved. The thoughtful comments of two anonymous reviewers are also greatly appreciated.

A.Q. was supported by Ministerio de Educación y Ciencia (Spain) with grant CGL2005-06549-CO2-01; P.J.N. was supported by the Smithsonian Institution and NSF Division of

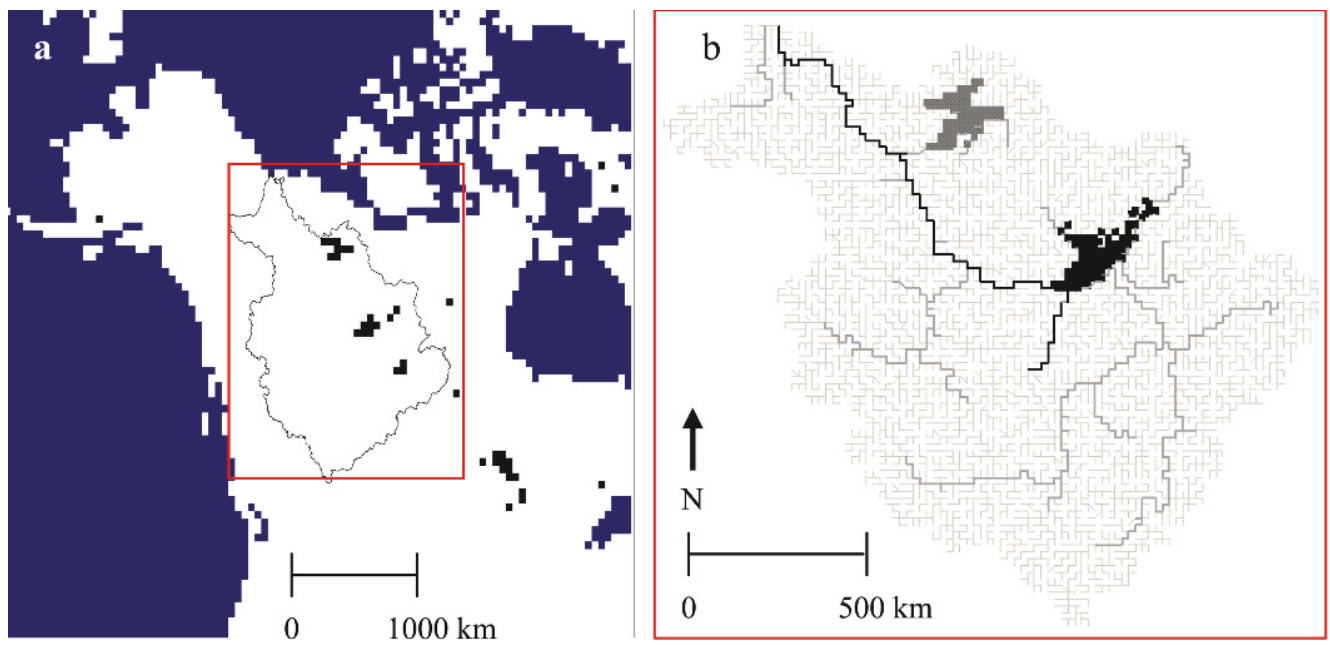

Fig. 3. Domains for Mackenzie River basin simulations from the Mackenzie global energy and water cycle experiment (GEWEX) study: (a) the 50-km horizontal resolution grid of the Canadian regional climate model; (b) the $20-\mathrm{km}$ horizontal grid for the river routing scheme WATROUTE indicating the resolved stream channel network as well as Great Bear and Great Slave lakes. Adapted from MacKay et al. (2003). 
Environmental Biology grant 0552283; and L.d.S.D. and W.M.M. were supported by grant 817.01 .007 of the Earth and Life Science Foundation (ALW), which is subsidized by the Netherlands Organization for Scientific Research (NWO).

\section{References}

Abril, G., AND others. 2005. Carbon dioxide and methane emissions and the carbon budget of a 10-year-old tropical reservoir (Petit-Saut, French Guiana). Glob. Biogeochem. Cycles 19: GB4007, doi: 10.1029/2005GB002457.

Adrian, R., R. Deneke, U. Mischke, R. Stellmacher, and P. LEDERER. 1995. Long-term study of the Heiligensee (19751992) - evidence for effects of climatic-change on the dynamics of eutrophied lake ecosystems. Arch. Hydrobiol. 133: 315-337.

- N. Walz, T. Hintze, S. Hoeg, and R. Rusche. 1999. Effects of ice duration on the plankton succession during spring in a shallow polymictic lake. Freshw. Biol. 41: 621623.

- AND OTHERS. 2009. Lakes as sentinels of present climate change. Limnol. Oceanogr. 54.

Andersen, H. E., B. Kronvang, S. E. Larsen, C. C. Hoffmann, T. S. Jensen, and E. K. Rasmussen. 2006. Climate-change impacts on hydrology and nutrients in a Danish lowland river basin. Sci. Tot. Environ. 365: 223-237.

Arain, M. A., T. A. Black, A. G. Barr, P. G. Jarvis, J. M. Massheder, D. L. Verseghy, and N. Nesic. 2002. Effects of seasonal and interannual climate variability on net ecosystem productivity of boreal deciduous and conifer forests. Can. J. For. Res. 32: 878-891.

Banerjee, S., and S. Macintyre. 2004. The air-water interface: Turbulence and scalar exchange, p. 181-237. In J. Grue, P. L. F. Liu, and G. K. Pedersen [eds.], Advances in coastal and ocean engineering. World Scientific.

Bastviken, D., J. Cole, M. Pace, And L. Tranvik. 2004. Methane emissions from lakes: Dependence of lake characteristics, two regional assessments, and a global estimate. Glob. Biogeochem. Cycles 18: GB4009, doi: 10.1029/2004GB002238.

$\longrightarrow,-, \longrightarrow$, AND M. C. VAN DE Bogert. 2008. Fates of methane from different lake habitats: Connecting wholelake budgets and $\mathrm{CH} 4$ emissions. J. Geophys. Res. 113: G02024, doi: 10.1029/2007JG000608.

Bates, G. T., S. W. Hostetler, and F. Giorgi. 1995. Two-year simulation of the Great Lakes region with a coupled modeling system. Monthly Weather Rev. 123: 1505-1522.

Belzile, C., W. Vincent, J. Gibson, And P. van Hove. 2001. Biooptical characteristics of the snow, ice, and water column of a perennially ice-covered lake in the High Arctic. Can. J. Fish. Aquat. Sci. 58: 2405-2418.

Benndorf, J., J. Kranich, T. Mehner, and A. Wagner. 2001. Temperature impact on the midsummer decline of Daphnia galeata: An analysis of long-term data from the biomanipulated Bautzen Reservoir (Germany). Freshw. Biol. 46: 199211.

Birge, E. A., C. Juday, And H. W. March. 1927. The temperature of the bottom deposits of Lake Mendota: A chapter in the heat exchanges of the lake. Trans. Wisc. Acad. Sci. 23: 189-231.

Black, T. A., AND OTHERS. 2000. Increased carbon sequestration by a boreal deciduous forest in years with a warm spring. Geophys. Res. Lett. 27: 1271-1274.

Bleiker, W., ANd F. Schanz. 1997. Light climate as the key factor controlling the spring dynamics of phytoplankton in Lake Zürich. Aquat. Sci. 59: 135-157.
Blenckner, T., A. Omstedt, and M. Rummukainen. 2002. A Swedish case study of contemporary and possible future consequences of climate change on lake function. Aquat. Sci. 64: $171-184$.

Blumberg, A. F., And D. M. Di Toro. 1990. Effects of climate warming on dissolved oxygen concentrations in Lake Erie. Trans. Am. Fish. Soc. 119: 210-223.

BonAn, G. B. 1995. Sensitivity of a GCM simulation to inclusion of inland water surfaces. J. Clim. 8: 2691-2704.

Bowling, L., D. Kane, R. Gieck, L. Hinzman, and D. LETTENMAiER. 2003. The role of surface storage in a lowgradient Arctic watershed. Water Resour. Res. 39: 1087-1099, doi: 10.1029/2002WR001466.

Brewer, M. C., L. D. Carter, and R. Glenn. 1993. Sudden drainage of a thaw lake on the Alaskan Arctic coastal plain, p. 48-53. In Proceedings of the Sixth International Conference on Permafrost. South China Univ. of Technology Press.

Carpenter, S. 2003. Regime shifts in lake ecosystems: Patterns and variation. Book 15. Excellence in ecology. Int. Ecology Institute. Oldendorf/Luhe.

- D. Ludwig, And W. A. BRock. 1999. Management of eutrophication for lakes subject to potentially irreversible change. Ecol. Appl. 9: 751-771.

Chen, Y.-H., AND R. G. Prinn. 2006. Estimation of atmospheric methane emission between 1996 and 2001 using a threedimensional global chemical transport model. J. Geophys. Res. 111: D10307, doi: 10.1029/2005JD006058.

Coops, H., M. Beklioglu, and T. L. Crisman. 2003. The role of water-level fluctuations in shallow lake ecosystems-workshop conclusions. Hydrobiologia 506-509: 23-27.

Cushing, D. H. 1990. Plankton production and year-class strength in fish populations - an update of the match mismatch hypothesis. Adv. Mar. Biol. 26: 249-293.

Danis, P.-A., U. von Grafenstein, V. Masson-Delmotte, S. Planton, D. Gerdeaux, and J.-M. Moisselin. 2004. Vulnerability of two European lakes in response to future climatic changes. J. Geophys.Res. 31: L21507, doi: 10.1029/ 2004GL020833.

De Senerpont Domis, L. N., W. M. Mooij, S. Hulsmann, E. H. van Nes, and M. Scheffer. 2007. Can overwintering versus diapausing strategy in Daphnia determine match-mismatch events in zooplankton-algae interactions? Oecologia 150: $682-698$.

Downing, J. A., AND others. 2006. The global abundance and size distribution of lakes, ponds, and impoundments. Limnol. Oceanogr. 51: 2388-2397.

Elliott, J. A., A. E. Irish, And C. S. Reynolds. 2002. Predicting the spatial dominance of phytoplankton in a light limited and incompletely mixed eutrophic water column using the PROTECH model. Freshw. Biol. 47: 433-440.

- S. J. Thackeray, C. Huntingford, and R. G. Jones. 2005. Combining a regional climate model with a phytoplankton community model to predict future changes in phytoplankton in lakes. Freshw. Biol. 50: 1404-1411.

ELo, A.-R. 2005. Modelling of summer stratification of morphologically different lakes. Nord. Hydrol. 36: 281-294. . 2007. The energy balance and vertical thermal structure of two small boreal lakes in summer. Boreal Environ. Res. 12: 585-600.

- , T. Huttula, A. Peltonen, and J. Virta. 1998. The effects of climate change on the temperature conditions of lakes. Boreal Environ. Res. 3: 137-150.

Emmerton, C. A., L. F. W. Lesack, and P. Marsh. 2007. Lake abundance, potential water storage, and habitat distribution in the Mackenzie River Delta, western Canadian Arctic. Water Resour. Res. 43: W05419, doi: 10.1029/2006WR005139. 
Engle, D., and J. Melack. 2000. Methane emissions from an Amazon floodplain lake: Enhanced release during episodic mixing and during falling water. Biogeochemistry 51: 71-90.

Fang, X., And H. G. Stefan. 1996. Dynamics of heat exchange between sediment and water in a lake. Water Resour. Res. 32: 1719-1728

, AND . 1997a. Temperature variability in lake sediments. Water Resour. Res. 34: 717-730.

, AND — 1997b. Simulated climate change effects on dissolved oxygen characteristics in ice-covered lakes. Ecol. Model. 103: 209-229.

Fee, E. J., R. E. Hecky, S. E. M. Kasian, and D. R. Cruikshank. 1996. Effects of lake size water clarity and climatic variability on mixing depths in Canadian shield lakes. Limnol. Oceanogr. 41: 912-920.

Ficke, A., C. Myrick, And L. Hansen. 2007. Potential impacts of global climate change on freshwater fisheries. Rev. Fish Bio. Fisheries 17: 581-613.

Follows, M. J., S. Dutkiewicz, S. Grant, and S. W. Chisholm. 2007. Emergent biogeography of microbial communities in a model ocean. Science 315: 1843-1846.

Fritsen, C. H., and J. C. Priscu. 1999. Seasonal change in the optical properties of the permanent ice cover on Lake Bonney, Antarctica: Consequences for lake productivity and phytoplankton dynamics. Limnol. Oceanogr. 44: 447454.

Gerten, D., And R. Adrian. 2001. Differences in the persistency of the North Atlantic Oscillation signal among lakes. Limnol. Oceanogr. 46: 448-455.

Goudsmit, G.-H., H. Burchard, F. Peeters, and A. Wüest. 2002. Application of $k-\varepsilon$ turbulence models to enclosed basins: The role of internal seiches. J. Geophys. Res. 107: 3230, doi: 10.1029/2001JC000954.

Goyette, S., N. A. McFarlane, and G. M. Flato. 2000. Application of the Canadian Regional Climate Model to the Laurentian Great Lakes region: Implementation of a lake model. Atmos. Ocean 38: 481-503.

Guérin, F., G. Abril, S. Richard, B. Burban, C. Reynouard, P. Seyler, and R. Delmas. 2006. Methane and carbon dioxide emissions from tropical reservoirs: Significance of downstream rivers. Geophys. Res. Lett. 33: L21407, doi: 10.1029/ 2006 GL027929.

- AND OTHERs. 2007. Gas transfer velocities of $\mathrm{CO}_{2}$ and $\mathrm{CH}_{4}$ in a tropical reservoir and its river downstream. J. Mar. Syst. 66: 161-172, doi: 10.1016/j.jmarsys.2006.03.019.

Guo, S., H. Leighton, And M. MacKay. 2007. Surface-absorbed and top-of-atmosphere radiation fluxes for the Mackenzie River basin from satellite observations and a regional climate model and an evaluation of the model. Atmos. Ocean 45: $129-139$.

Hanson, P. C., A. I. Pollard, D. L. Bade, K. Predick, S. R. Carpenter, And J. A. Foley. 2004. A model of carbon evasion and sedimentation in temperate lakes. Glob. Change Biol. 10: 1285-1298.

Hargreaves, B. R. 2003. Water column optics and penetration of UVR, p. 59-105. In E. W. Helbling and H. E. Zagarese [eds.], UV effects in aquatic organisms and ecosystems. Comprehensive series in photochemistry and photobiology. Royal Society of Chemistry.

Henderson-Sellers, B. 1985. New formulation of eddy diffusion thermocline models. Appl. Math. Model. 9: 441-446.

-, AND A. M. Davies. 1989. Thermal stratification modeling for oceans and lakes. Ann. Rev. Numer. Fluid Mech. Heat Transf. 2: 86-156.
Hinkel, K. M., R. C. Frohn, F. E. Nelson, W. R. Eisner, and R. A. BECK. 2005. Morphometric and spatial analysis of thaw lakes and drained thaw lake basins in the Western Arctic Coastal Plain, Alaska. Permafr. Perigl. Proc. 16: 327-341.

- B. Jones, W. Eisner, C. Cuomo, R. Beck, and R. Frohn. 2007. Methods to assess natural and anthropogenic thaw lake drainage on the western Arctic coastal plain of northern Alaska. J. Geophys. Res. 112: 1-9.

Hondzo, M., And H. Stefan. 1993. Regional water temperature characteristics of lakes subjected to climate change. Clim. Change 24: 187-211.

Hostetler, S. W., And P. J. Bartlein. 1990. Simulation of lake evaporation with application to modeling lake level variations of Harney-Malheur Lake, Oregon. Water Resour. Res. 26: 2603-2612.

, AND F. GioRgi. 1995. Effects of a $2 \times \mathrm{CO} 2$ climate on two large lake systems: Pyramid Lake, Nevada, and Yellowstone Lake, Wyoming. Glob. Planet. Change 10: 43-54.

- , G. T. Bates, And P. J. Bartlein. 1994. Lakeatmosphere feedbacks associated with paleolakes Bonneville and Lahontan. Science 263: 665-668.

Humphries, S. E., And V. D. Lyne. 1988. Cyanophyte bloomsthe role of cell buoyancy. Limnol. Oceanogr. 33: 79-91.

Huttula, T., A. Peltonen, A. Bilaletin, and M. Saura. 1992. The effects of climatic change on lake ice and water temperature. Aqua Fenn. 22: 129-142.

Ibelings, B. W., L. R. Mur, and A. E. Walsby. 1991. Diurnal changes in buoyancy and vertical distribution in populations of Microcystis in 2 shallow lakes. J. Plankton Res. 13: 419-436.

Imberger, J. 1985. The diurnal mixed layer. Limnol. Oceanogr. 30: $737-770$.

Jassby, A. D., J. E. Reuter, and C. R. Goldman. 2003. Determining long-term water quality change in the presence of climate variability: Lake Tahoe (U.S.A.). Can. J. Fish Aquat. Sci. 60: 1452-1461.

Jöhnk, K. D., J. Huisman, J. Sharples, B. Sommeijer, P. M. Visser, ANd J. M. Stroom. 2008. Summer heatwaves promote blooms of harmful cyanobacteria. Glob. Change Biol. 14: 495-512.

Joyce, J., And P. W. Jewell. 2003. Physical controls on methane ebullition from reservoirs and lakes. Environ. Eng. Geosci. 9: 167-178, doi:10.2113/9.2.167.

Kemenes, A., B. R. Forsberg, and J. M. Melack. 2007. Methane release below a tropical hydroelectric dam. Geophys. Res. Lett. 34: L12809, doi: 10.1029/2007GL029479.

KIRK, J. T. O. 1994. Light and photosynthesis in aquatic ecosystems, 2nd ed. Cambridge Univ. Press.

Koster, R. D., and M. J. Suarez. 1992. Modeling the land surface boundary in climate models as a composite of independent vegetation stands. J. Geophys. Res. 97: 26972715.

KRINNER, G. 2003. Impact of lakes and wetlands on boreal climate J. Geophys. Res. 108: 4520, doi: 10.1029/2002JD002597.

Kusumastuti, D. I., I. Struthers, M. Sivapalan, and D. A. REYNOLDS. 2007. Threshold effects in catchment storm response and the occurrence and magnitude of flood events: Implications for flood frequency. Hydrol. Earth Syst. Sci. 11: $1515-1528$

Lehman, J. T. 2002. Mixing patterns and plankton biomass of the St. Lawrence Great Lakes under climate change scenarios. J. Great Lakes Res. 28: 583-596.

Litchman, E., C. A. Klausmeier, J. R. Miller, O. M. Schofield, AND P. G. FALKOWSKI. 2006. Multi-nutrient, multi-group model of present and future oceanic phytoplankton communities. Biogeosciences 3: 585-606. 
Lunngemyr, P., N. Gustafsson, and A. Omstedt. 1996. Parameterization of lake thermodynamics in a high-resolution weather forecasting model. Tellus 48A: 608-621.

Lohrenz, S. E., G. L. Fahnenstiel, D. F. Millie, O. M. E. Schofield, T. Johengen, and T. Bergmann. 2004. Spring phytoplankton photosynthesis, growth, and primary production and relationships to a recurrent coastal sediment plume and river inputs in southeastern Lake Michigan. J. Geophys. Res. 109: C10S14, doi: 10.1029/2004JC002383.

Mackay, J. R. 1988. Catastrophic lake drainage, Tuktoyaktuk Peninsula area, District of Mackenzie, p. 83-90. In Current research, Part D, Geological Survey Canada, Paper 88-1D.

- 1992. Lake stability in an ice-rich permafrost environment: Examples from the western Arctic coast, p. 1-26. In R. D. Robarts and M. L. Bothwell [eds.], Aquatic ecosystems in semiarid regions: Implications for resource management. Nat. Hydrol. Res. Inst. Symp. Ser. 7. Environment Canada.

MacKay, M. D., P. Bartlett, E. Chan, C. Derksen, S. Guo, and H. Leighton. 2006. On the simulation of regional scale sublimation over boreal and agricultural landscapes. Atmos. Ocean 44: 289-304.

-, F. Seglenieks, D. Verseghy, E. D. Soulis, K. R. Snelgrove, A. Walker, And K. Szeto. 2003. Modeling Mackenzie basin surface water balance during cages with the Canadian regional climate model. J. Hydromet. 4: 748-767.

Makhov, G. A., And N. M. Bazhin. 1999. Methane emission from lakes. Chemosphere 38: 1453-1459.

Malmaeus, J. M., T. Blenckner, H. Markensten, And I. Persson. 2006. Lake phosphorus dynamics and climate warming: A mechanistic model approach. Ecol. Model. 190: $1-14$.

Marsh, P., and L. F. W. Lesack. 1996. The hydrologic regime of perched lakes in the Mackenzie Delta: Potential responses to climate change. Limnol. Oceanogr. 41: 849-856.

Matzinger, A., AND others. 2007. Eutrophication of ancient Lake Ohrid: Global warming amplifies detrimental effects of increased nutrient inputs. Limnol. Oceanogr. 52: 338-353.

McGinnis, D. F., J. Greinert, Y. Artemov, S. E. Beaubien, And A. WÜEST. 2006. The fate of rising methane bubbles in stratified reservoirs: How much methane reaches the atmosphere? J. Geophys. Res. 111: C09007, doi: 10.1029/2005JC003183.

Mieleitner, J., And P. Reichert. 2008. Modelling functional groups of phytoplankton in three lakes of different trophic state. Ecol. Model. 211: 279-291.

Mironov, D. V. 2006. Parameterization of lakes in numerical weather prediction. Part 1: Description of a lake model. Technical Note, German Weather Service.

- S. D. Golosov, S. S. Zilitinkevich, K. D. Kreiman, And A. Terzhevik. 1991. Seasonal changes of temperature and mixing conditions in a lake, p. 74-90. In S. S. Zilitinkevich [ed.], Modelling air-lake interaction. Physical background. Springer.

Moed, J. R., And H. L. Hoogveld. 1982. The algal periodicity in Tjeukemeer during 1968-1978. Hydrobiologia 95: 205-223.

Mooij, W. M., J. H. Janse, L. N. De Senerpont Domis, S. Hulsmann, and B. W. IBelings. 2007. Predicting the effect of climate change on temperate shallow lakes with the ecosystem model PCLake. Hydrobiologia 584: 443-454.

- , L. N. De Senerpont Domis, and S. Hülsmann. 2008. The impact of climate warming on water temperature, timing of hatching and young-of-the-year growth of fish in shallow lakes in the Netherlands. J. Sea Res. 60: 32-43.

Moore, J. K., S. C. Doney, J. A. Kleypas, D. M. Glover, and I. Y. Fung. 2002. An intermediate complexity marine ecosystem model for the global domain. Deep-Sea Res. II 49: 403-462.
Neale, P. J., And D. J. Kieber. 2000. Assessing biological and chemical effects of UV in the marine environment: Spectral weighting functions, p. 61-83. In R. E. Hester and R. M. Harrison [eds.], Causes and environmental implications of increased UV-B. radiation. Issues in environmental science and technology. Royal Society of Chemistry.

NiILer, P. P., AND E. B. Kraus. 1977. One-dimensional models of the upper ocean, p. 143-172. In E. B. Kraus [ed.], Modelling and prediction of the upper layers of the ocean. Pergamon Press.

O'Reilly, C. M., S. R. Alin, P. D. Plisnier, A. S. Cohen, and B. A. MCKeE. 2003. Climate change decreases aquatic ecosystem productivity of Lake Tanganyika, Africa. Nature 424: $766-768$.

Omstedt, A., And L. Axell. 1998. Modelling the seasonal, interannual, and long-term variations of salinity and temperature in the Baltic proper. Tellus 50A: 637-652.

—, AND L. Nyberg. 1996. Response of Baltic sea ice to seasonal, interannual forcing and climate change. Tellus 48A: 644-662.

- AND J. SAhlberg. 1983. Measured and numerically simulated autumn cooling in the Bay of Bothnia. Tellus 35A: 231-240.

Ostrovsky, I. 2003. Methane bubbles in Lake Kinneret: Quantification and temporal and spatial heterogeneity. Limnol. Oceanogr. 48: 1030-1036.

Paerl, H. W., and J. Huisman. 2008. Climate-blooms like it hot. Science 320: 57-58.

Peeters, F., D. M. Livingstone, G.-H. Goudsmit, R. Kipfer, And R. Forster. 2002. Modeling 50 years of historical temperature profiles in a large central European lake. Limnol. Oceanogr. 47: 186-197.

— D. Straile, A. Lorke, and D. M. Livingstone. $2007 a$. Earlier onset of the spring phytoplankton bloom in lakes of the temperate zone in a warmer climate. Glob. Change Biol. 13: $1898-1909$.

mining AND D. OLLINGER, 2007b. mixing and phytoplankton spring bloom development in a deep lake. Limnol. Oceanogr. 52: 286-298.

Persson, I., And I. D. Jones. 2008. The effect of water colour on lake hydrodynamics: A modelling study. Freshw. Biol. 53: 2345-2355, doi: 10.1111/j.1365-2427.2008.02049.x.

PiaO, S., AND others. 2007. Net carbon dioxide losses of northern ecosystems in response to autumn warming. Nature 451: 49-52, doi: 10.1038/nature06444.

Pienitz, R., And W. F. Vincent. 2000. Effect of climate change relative to ozone depletion on UV exposure in subarctic lakes. Nature 404: 484-487.

Pitman, A. J. 1991. A simple parameterization of sub-grid scale open water for climate models. Clim. Dyn. 6: 99-112.

Pivovarov, A. A. 1974. Thermal conditions in freezing lakes and rivers. John Wiley and Sons.

Plug, L. J., C. Wallis, and B. M. Scott. 2008. Tundra lake changes from 1978 to 2001 on the Tuktoyaktuk Peninsula, western Canadian Arctic. Geophys. Res. Lett. 35: L03502, doi: 10.1029/2007GL032303.

Preston, B. 2006. Risk-based reanalysis of the effects of climate change on U.S. cold-water habitat. Clim. Change 76: 91-119.

- AND R. N. Jones. 2008. Evaluating sources of uncertainty in Australian runoff projections. Adv. Water Resour. 31: $758-775$.

Quayle, W. C., L. S. Peck, H. Peat, J. C. Ellis-Evans, and P. R. Harrigan. 2002. Extreme responses to climate change in Antarctic lakes. Science 295: 645-645.

Ramos, F. M., AND others. 2006. Extreme event dynamics in methane ebullition fluxes from tropical reservoirs. Geophys. Res. Lett. 33: L21404, doi: 10.1029/2006GL027943. 
Reeders, H. H., P. C. M. Boers, D. T. Van Der molen, and T. H. Helmerhorst. 1998. Cyanobacterial dominance in the Lakes Veluwemeer and Wolderwijd, The Netherlands. Water Sci. Technol. 37: 85-92.

Reynolds, C. S. 1997. Vegetation processes in the pelagic: A model for ecosystem theory. Ecology Institute.

Richey, J. E., J. M. Melack, A. K. Aufdenkampe, V. M. Ballester, And L. Hess. 2002. Outgassing from Amazonian rivers and wetlands as a large tropical source of atmospheric carbon dioxide. Nature 416: 617-620.

Rip, W., M. Ouboter, And H. Los. 2007. Impact of climatic fluctuations on Characeae biomass in a shallow, restored lake in The Netherlands. Hydrobiologia 584: 415-424.

Robarts, R. D., AND T. Zohary. 1987. Temperature effects on photosynthetic capacity, respiration, and growth rates of bloom forming cyanobacteria. NZ J. Mar. Fresh. Res. 21: 391-399.

Rodriguez-Iturbe, I., And J. B. Valdes. 1979. The geomorphic structure of hydrologic response. Water Resour. Res. 15: $1409-1420$

Rummukainen, M., AND others. 2001. A regional climate model for northern Europe: Model description and results from the downscaling of two GCM control simulations. Clim. Dyn. 17: 339-359.

SAHLBERG, J. 1988. Modelling the thermal regime of a lake during the winter season. Cold Reg. Sci. Technol. 15: 151-159.

St. Louis, V. L., C. A. Kelly, É. Duchemin, J. W. M. Rudd, And D. M. Rosenberg. 2000. Reservoir surfaces as sources of greenhouse gases to the atmosphere: A global estimate. BioScience 50: 766-775.

Schalau, K., K. Rinke, D. Straile, and F. Peeters. 2008. Temperature is the key factor explaining interannual variability of Daphnia development in spring - a modelling study. Oecologia 157: 531-543.

Scheffer, M., S. H. Hosper, M. L. Meijer, B. Moss, and E. JEPPESEN. 1993. Alternative equilibria in shallow lakes. Trends Ecol. Evol. 8: 275-279.

, D. Straile, E. H. van Nes, and H. Hosper. 2001. Climatic warming causes regime shifts in lake food webs. Limnol. Oceanogr. 46: 1780-1783.

Schindler, D. W., P. J. Curtis, S. E. Bayley, B. R. Parker, K. G. Beaty, and M. P. Stainton. 1997. Climate-induced changes in the dissolved organic carbon budgets of boreal lakes. Biogeochemistry 36: 9-28.

- AND OTHERS. 1996. The effects of climate warming on the properties of boreal lakes and streams at the Experimental Lakes Area, northwestern Ontario. Limnol. Oceanogr. 41: 1004-1017.

SCHMID, M., AND OTHERs. 2007. Sources and sinks of methane in Lake Baikal: A synthesis of measurements and modeling. Limnol. Oceanogr. 52: 1824-1837.

Shapiro, J. 1997. The role of carbon dioxide in the initiation and maintenance of blue-green dominance in lakes. Freshw. Biol. 37: $307-323$.

Small, E. E., L. C. Sloan, S. Hostetler, and F. Giorgi. 1999. Simulating the water balance of the Aral Sea with a coupled regional climate-lake model. J. Geophys. Res. 104: 65836602.

Sмith, I. R. 1979. Hydraulic conditions in isothermal lakes. Freshw. Biol. 9: 119-145.

Smith, L. C., Y. Sheng, and G. M. Macdonald. 2007. A first pan-arctic assessment of the influence of glaciation, permafrost, topography and peatlands on northern hemisphere lake distribution. Permafr. Perigl. Proc. 18: 201-208.

arctic lakes. Science 308: 1429.
Sondergatrd, M., M. P. Jensen, And E. Jeppesen. 2003. Role of sediment and internal loading of phosphorus in shallow lakes. Hydrobiologia 506: 135-145.

Song, Y., F. Semazzi, L. Xie, and L. Ogallo. 2004. A coupled regional climate model for the Lake Victoria basin of East Africa. Int. J. Climatol. 24: 57-75.

Spence, C. 2001. Subgrid runoff processes and hydrological modeling in the subarctic Canadian Shield, p. 113-116. In Soil-vegetation-atmosphere transfer schemes and large-scale hydrological models. Proceedings of a symposium held during the 6th IAHS Scientific Assembly at Maastricht, The Netherlands, July 2001, IAHS Publ. No. 270.

Spigel, R. H., J. Imberger, and K. N. Rayner. 1986. Modeling the diurnal mixed layer. Limnol. Oceanogr. 31: 533-556.

Steele, J. H. 1985. A comparison of terrestrial and marine ecological systems. Nature 313: 355-358.

Stefan, H. G., And X. FAng. 1994. Dissolved oxygen model for regional lake analysis. Ecol. Model. 71: 37-68.

StigebrandT, A. 1987. A model for the vertical circulation of the Baltic deep water. J. Phys. Ocean. 17: 1772-1785.

Straile, D. 2000. Meteorological forcing of plankton dynamics in a large and deep continental European lake. Oecologia 122: 44-50.

- 2002. North Atlantic Oscillation synchronizes food-web interactions in central European lakes. Proc. R. Soc. Lond. 269: 391-395.

- AND R. Adrian. 2000. The North Atlantic Oscillation and plankton dynamics in two European lakes - two variations on a general theme. Glob. Change Biol. 6: 663-670.

, R. Eckmann, T. Jungling, G. Thomas, and H. Loffler. 2007. Influence of climate variability on whitefish (Coregonus lavaretus) year-class strength in a deep, warm monomictic lake. Oecologia 151: 521-529.

, K. Johnk, And H. Rossknecht. 2003. Complex effects of winter warming on the physiochemical characteristics of a deep lake. Limnol. Oceanogr. 48: 1432-1438.

Svensson, U. 1978. A mathematical model of the seasonal thermocline. Ph.D. thesis. University of Lund, Sweden.

Swift, T. J., J. Perez-Losada, S. G. Schladow, J. E. Reuter, A. D. JASSBY, AND C. R. Goldman. 2006. Water clarity modeling in Lake Tahoe: Linking suspended matter characteristics to Secchi depth. Aquat. Sci. 68: 1-15.

Tanabe, Y., S. Kudoh, S. Imura, and M. Fukuchi. 2008. Phytoplankton blooms under dim and cold conditions in freshwater lakes of East Antarctica. Polar Biol. 31: 199-208.

Thérien, N., And K. Morrison. 2005. Modeling the GHG emission from hydroelectric reservoirs, p. 596-635. In A. Tremblay, L. Varfalvy, C. Roehm, and M. Garneau [eds.], Greenhouse gas emissions - fluxes and processes: Hydroelectric reservoirs and natural environments. Springer-Verlag.

TranviK, L. J., AND others. 2009. Lakes and reservoirs as regulators of carbon cycling and climate. Limnol. Oceanogr. 54: 2298-2314.

Verseghy, D., N. A. McFarlane, and M. Lazare. 1993. CLASS - a Canadian land surface scheme for GCMs II. Vegetation model and coupled runs. Int. J. Climatol. 13: 347-370.

Vincent, W. F. 1988. Microbial ecosystems of Antarctica. Cambridge Univ. Press.

, AND A. QuesADA. 1994. Ultraviolet radiation effects on cyanobacteria: Implications for Antarctic microbial ecosystems, p. 111-124. In C. S. Weiler and P. A. Penhale [eds.], Antarctic research series, ultraviolet radiation in Antarctica: Measurements and biological effects. American Geophysical Union. 
Wagner, A., S. Hülsmann, H. Dörner, M. Janssen, U. Kahl, T. Mehner, and J. Benndorf. 2004. Initiation of the midsummer decline of Daphnia as related to predation, nonconsumptive mortality and recruitment: A balance. Arch. Hydrobiol. 160: 1-23.

Walter, K. M., L. C. Smith, and F. S. Chapin Iir. 2007. Methane bubbling from northern lakes: Present and future contributions to the global methane budget. Phil. Trans. R. Soc. 365: 1657-1676, doi: 10.1098/rsta.2007.2036.

Weyhenmeyer, G. A., T. Blenckner, and K. Pettersson. 1999. Changes of the plankton spring outburst related to the North Atlantic Oscillation. Limnol. Oceanogr. 44: 1788-1792.

—, AND OTHERS. 2007. Nitrate-depleted conditions on the increase in shallow northern European lakes. Limnol. Oceanogr. 52: 1346-1353.

Williamson, C. E., J. E. Saros, and D. W. Schindler. 2009. Sentinels of change. Science 323: 887-888, doi: 10.1126/ science. 1169443.

Winder, M., J. E. Reuter, and S. G. Schladow. 2009. Lake warming favors small-sized planktonic diatom species. Proc. R. Soc. B 276: 1656, doi: 10.1098/rspb.2008.1200.
, AND D. E. SChindler. 2004. Climate change uncouples trophic interactions in an aquatic ecosystem. Ecology 85: 2100-2106.

Woo, M.-K. 2000. Permafrost and hydrology, p. 57-96. In M. Nuttall and T. Callaghan [eds.], The Arctic: Environment, people, policy. Harwood.

Wüest, A., And A. LoRke. 2003. Small-scale hydrodynamics in lakes. Annu. Rev. Fluid Mech. 35: 373-412.

Yeates, P. S., And J. Imberger. 2004. Pseudo two-dimensional simulations of internal and boundary fluxes in stratified lakes and reservoirs. Int. J. River Basin Manag. 1: 297-319.

Yoshikawa, K., And L. D. Hinzman. 2003. Shrinking thermokarst ponds and groundwater dynamics in discontinuous permafrost near Council, Alaska. Permafr. Perigl. Proc. 14: 151-160.

Associate editors: Warwick F. Vincent and John P. Smol

Received: 17 October 2008

Accepted: 20 May 2009

Amended: 16 June 2009 